\title{
Perbedaan flow saliva anak usia 11-12 tahun dengan risiko karies tinggi dan rendah
}

\author{
${ }^{1}$ Disa ratna nurhasanah ${ }^{1}$, Dudi Aripin ${ }^{1 *}$, Ervin Rizali $^{2}$ \\ ${ }^{1}$ Departemen Konservasi Gigi, Fakultas Kedokteran Gigi Universitas Padjadjaran, Indonesia \\ ${ }^{2}$ Departemen Oral Biologi, Fakultas Kedokteran Gigi Universitas Padjadjaran, Indonesia \\ *Korespondensi: dudi.aripin@fkg.unpad.ac.id
}

\begin{abstract}
ABSTRAK
Pendahulan: Mulut merupakan rongga fungsional yang menjadi pintu awal masuknya makanan ke dalam tubuh, didalamnya terdapat cairan kompleks yaitu saliva. Cairan yang kompleks ini diproduksi dan disekresikan oleh kelenjar saliva. Hasil produksi kelenjar saliva dapat membantu kestabilan lingkungan di sekitar rongga mulut. Rongga mulut saliva disekresikan sebanyak 0.5 - 1.5 liter/hari melalui duktus pada kelenjar saliva. Tujuan penelitian ini adalah untuk mendapatkan data mengenai perbedaan flow saliva pada anak usia 11-12 tahun dengan risiko karies tinggi dan rendah di Sekolah Dasar Cikawari Kabupaten Bandung. Metode: Jenis penelitian analitik observasional secara cross sectional. Variabel penelitian adalah saliva, flow saliva, karies. Populasi dan sampel penelitian adalah anak usia 11-12 tahun yang hadir di sekolah tempat penelitian. Penelitian dilakukan di Sekolah Dasar Cikawari Kabupaten Bandung pada bulan Desember tahun 2015. Hasil: Hasil uji perbandingan dengan menggunakan independent sample t-test menunjukkan nilai mean pada kelompok risiko karies tinggi sebesar 0,302 dengan standar deviasi 0,200 dan nilai mean pada kelompok risiko karies rendah sebesar 0,512 dengan standar deviasi 0,270. P-value sebesar $0.015<0,05$. Simpulan : Terdapat perbedaan flow saliva tanpa stimulasi pada anak usia 11-12 tahun dengan risiko karies tinggi dan rendah di SDN Cikawari Kabupaten Bandung.
\end{abstract}

Kata kunci: Saliva, flow saliva, karies gigi

\section{The Difference of saliva of age children 11-12 years with with high and low caries risk}

\section{ABSTRACT}

Introduction: The mouth is a functional cavity that is becomes the intial entry of food into the body, there is a complex fluid in the saliva .This complex produced and fluid secreted by the salivary gland .The liquidation of the salivary gland could help environmental stability around the cavity of the mouth. On the oral cavity saliva is secreted as much as 0.5-1.5 liters / day through the ductus in the salivary gland. The purpose of this research is to obtain data on the differences flow saliva on children aged 11-12 years with risk caries high and low in Cikawari Elementary School Bandung Districk. Methods: this research was analytic observational research in cross sectional. Variable research is saliva, flow saliva, caries. The population and study sample were children aged 11-12 years who were present at the school. The research was done in Cikawari Elementary School Bandung Districk in December 2015. Results: this research result indicates there were differences flow salivary without stimulation between the risk of high and low caries. Conclusion: there is a difference in flow of saliva without stimulation in children aged 11-12 years with high and low caries risk in SDN Cikawari, Bandung Regency. 


\section{PENDAHULUAN}

Mulut merupakan rongga fungsional yang menjadi pintu awal masuknya makanan ke dalam tubuh, didalamnya terdapat cairan kompleks yaitu saliva. Cairan yang kompleks ini diproduksi dan disekresikan oleh kelenjar saliva. ${ }^{1,2}$ Sekresi kelenjar saliva tidak selalu menghasilkan jumlah saliva yang konstan, Patricia pada tahun 2008 dalam Humairi ${ }^{3}$ menjelaskan flow saliva dibagi menjadi tiga, yaitu normal, rendah dan sangat rendah. Flow saliva normal pada saat tidak distimulasi sekitar 0,25-0,3 $\mathrm{ml} /$ menit, rendah apabila flow saliva $0,1-0,25 \mathrm{ml} /$ menit dan flow saliva $<0,1 \mathrm{ml} /$ menit adalah yang sangat rendah.

Flow rate saliva merupakan pengaturan fisiologis flow sekresi saliva. Flow rate kelenjar saliva dapat distimulasi dengan cara: mekanis yaitu dengan pengunyahan, kimiawi yaitu dengan rangsangan rasa, neural yaitu melalui saraf simpatis dan parasimpatis, psikis dan rangsangan rasa sakit. ${ }^{4}$ Faktor-faktor yang mempengaruhi stimulus adalah tipe, intensitas, dan durasi stimulusnya. Bila diberi stimulus, flow akan meningkat menjadi 2,5-5 ml/menit. ${ }^{5,6}$ Flow rate saliva dapat mengalami perubahan akibat dari berbagai faktor antara lain rangsangan pengecapan, rangsangan psikologi, ataupun rangsangan akibat perawatan gigi misalnya karena peralatan dokter gigi. $^{5}$

Secara umum saliva berperan dalam proses perlindungan pada permukaan mulut, mengatur kandungan air, membantu dalam pencernaan makanan dan pengecapan ${ }^{7,8}$, perlindungan yang diberikan saliva terhadap gigi dan mulut dengan membentuk lapisan mukus pelindung pada membran mukosa yang akan bertindak sebagai barier terhadap iritan dan akan mencegah kekeringan. Saliva memiliki kemampuan melakukan aktivitas antibakterial dan antivirus oleh komponen antibody spesifik, saliva dapat membantu membersihkan gigi dan mulut dari debris makanan sehingga menghambat bakteri untuk berkembang biak dan membentuk plak dan karies dengan cepat. ${ }^{9}$

Fungsi saliva diatas erat hubungannya dengan proses terjadinya karies. Karies adalah salah satu penyakit kronis yang paling umum diderita masyarakat seluruh dunia, Karies merupakan hasil interaksi dari waktu ke waktu antara bakteri yang menghasilkan asam, substrat yang dapat dimetabolisme oleh bakteri, dan faktor host yang mencakup gigi dan saliva. Penyakit ini berkembang baik di mahkota dan akar gigi, dan dapat timbul pada anak usia dini sebagai kerusakan gigi agresif. ${ }^{10}$ Karies juga bisa terjadi karena kecepatan sekresi saliva menurun, yang menjadikan flow saliva menjadi rendah. Saliva menjadi kurang efektif dalam membersihkan gigi dan mulut. ${ }^{11}$

Kebersihan mulut yang kurang baik terdapat pada masyarakat di salah satu daerah di kabupaten Bandung terbukti dengan indeks DMF-S pada daerah tersebut bernilai 3,8 yang termasuk ke dalam kategori sedang menurut WHO dalam Hansen ${ }^{12}$, disana terdapat satu sekolah yang merupakan sekolah binaan Unpad yaitu Sekolah Dasar Cikawari yang berada jauh dari pusat kota, dan memiliki pengetahuan serta kesadaran yang rendah terhadap kesehatan gigi dan mulutnya.

Usia anak yang mudah dijangkau oleh usaha kesehatan gigi sekolah adalah anak usia 12 tahun. Selain itu, pada usia tersebut, anak lebih mudah diajak berkomunikasi Menurut WHO, usia 12 tahun ditetapkan sebagai usia pemantauan global untuk karies. ${ }^{12}$ Tujuan penelitian ini adalah untuk mendapatkan data mengenai perbedaan flow saliva pada anak usia 11-12 tahun dengan risiko karies tinggi dan rendah di Sekolah Dasar Cikawari kabupaten Bandung.

\section{METODE}

Jenis penelitian yang digunakan adalah analitik observasional secara cross sectional. Populasi dan sampel penelitian ini adalah seluruh anak usia 1112 tahun di Sekolah Dasar Cikawari kecamatan Cimenyan kabupaten Bandung. Sampel adalah saliva yang di ambil dari anak-anak Sekolah Dasar Cikawari dengan kriteria sebagai berikut: Anak-anak usia 1112 tahun Sekolah Dasar Cikawari; kondisi secara umum sehat; tidak sedang mengkonsumsi obat-obat; tidak sedang memakai alat ortodonti atau protesa; bersedia dijadikan naracoba (informed consent).

Sebelum penelitian akan dilakukan, sampel tidak diperkenankan untuk makan, minum, maupun membersihkan rongga mulutnya, selama kurun waktu 1-2 jam, dan selama pengumpulan saliva sampel tidak diperkenankan untuk berbicara, menggerakkan lidah, mengunyah, dan melakukan gerakan penelanan. Segera setelah sampel duduk yang nyaman, dilakukan pengumpulan saliva menggunakan metode spitting, yaitu sebagai berikut: 
posisi sampel duduk dengan tenang dan diam sambil menundukkan kepala. Sampel diinstruksikan untuk tidak menelan selama prosedur berlangsung. Sesaat sebelum prosedur pengumpulan dimulai, sampel diharuskan menelan semua sisa saliva yang ada di rongga mulut. Saliva dibiarkan mengumpul di dalam rongga mulut dan setiap menit saliva yang sudah terkumpul dikeluarkan ke dalam pot saliva.

Pengumpulan saliva dilakukan selama 2 menit. Hasil di catat dan di hitung hingga nilainya di dapat. Alat dan bahan yang digunakan adalah kaca mulut, sonde, pinset, sarung tangan, masker, pot saliva, gelas ukur, stopwatch, alat-alat tulis, kertas, lembar informed consent dan lembar pemeriksaan. Penelitian akan dilakukan di SDN Cikawari Kabupaten Bandung pada bulan Desember 2015. Hasil uji perbandingan flow saliva pada anak dengan risiko karies tinggi dan risiko karies rendah dengan menggunakan independent sample t-test.

\section{HASIL}

Penelitian ini dilakukan untuk mengetahui perbedaan flow saliva tanpa stimulasi pada subjek dengan risiko karies tinggi dan rendah. Subjek pada penelitian adalah anak usia 11-12 tahun di SDN Cikawari Kabupaten Bandung yang berjumlah 34 anak.

Data hasil pemeriksaan dengan menggunakan kategori indeks DMF-T menurut WHO pada Tabel 1

\begin{tabular}{|c|c|c|}
\hline \multirow[t]{2}{*}{ No. } & \multicolumn{2}{|c|}{ Flow saliva tanpa stimulasi (ml/menit) } \\
\hline & Risiko karies tinggi & Risiko karies rendah \\
\hline 1 & 0,36 & 0,32 \\
\hline 2 & 0,16 & 0,64 \\
\hline 3 & 0,54 & 0,40 \\
\hline 4 & 0,48 & 0,73 \\
\hline 5 & 0,16 & 0,20 \\
\hline 6 & 0,24 & 0,64 \\
\hline 7 & 0,10 & 0,40 \\
\hline 8 & 0,16 & 0,68 \\
\hline 9 & 0,10 & 1,32 \\
\hline 10 & 0,32 & 0,36 \\
\hline 11 & 0,20 & 0,40 \\
\hline 12 & 0,12 & 0,40 \\
\hline 13 & 0,72 & 0,40 \\
\hline 14 & 0,24 & 0,34 \\
\hline 15 & 0,48 & 0,52 \\
\hline 16 & 0,11 & 0,76 \\
\hline 17 & 0,64 & 0,20 \\
\hline
\end{tabular}

terdapat 17 subjek yang bernilai indeks DMF-T lebih besar dari 4,4 yang dikategorikan menjadi kelompok risiko karies tinggi dan 17 subjek yang bernilai indeks DMF-T lebih kecil dari 2,6 yang dikategorikan menjadi kelompok risiko karies rendah.

Gambar 1 menunjukkan bahwa rerata flow saliva tanpa stimulasi pada kelompok risiko karies tinggi lebih kecil dibandingkan dengan rerata flow saliva pada kelompok risiko karies rendah. Nilai flow saliva tanpa stimulasi pada kelompok risiko karies tinggi sebesar 0,302, sedangkan rerata flow saliva tanpa stimulasi pada kelompok risiko karies rendah sebesar 0,512 .

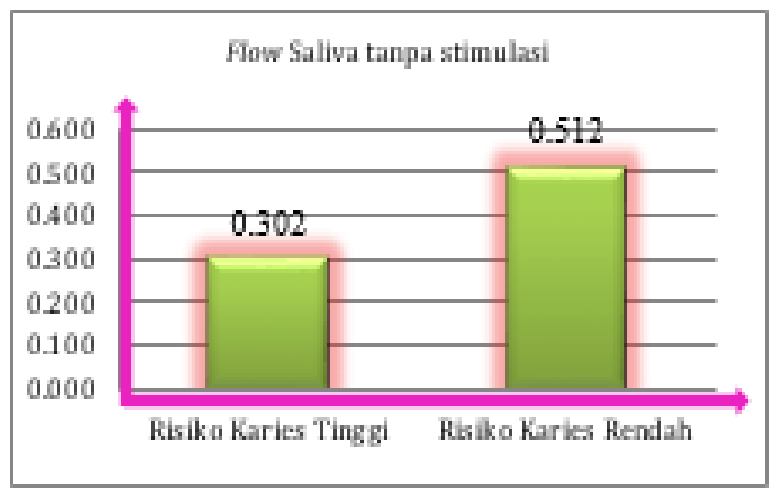

Grafik 1. Perbedaan flow saliva tanpa stimulasi pada kelompok risiko karies tinggi dan risiko karies rendah

Tabel 2. Perbedaan flow saliva berdasarkan kelompok risiko karies

Uji

\begin{tabular}{ccccc}
\multirow{2}{*}{ Kelompok } & \multicolumn{2}{c}{ perbandingan } & p-value & Kesimpulan \\
\cline { 2 - 3 } & Mean & SD & & \\
\hline Risiko karies tinggi & 0,302 & 0,200 & 0.015 & Signifikan \\
Risiko karies rendah & 0,512 & 0,270 & & \\
\hline
\end{tabular}

Hasil uji perbandingan dengan menggunakan independent sample t-test pada Tabel 2 memperlihatkan nilai mean pada kelompok risiko karies tinggi sebesar 0,302 dengan standar deviasi 0,200 dan nilai mean pada kelompok risiko karies rendah sebesar 0,512 dengan standar deviasi 0,270. $P$-value sebesar 0,015 $<0,05$ yang menunjukkan bahwa terdapat perbedaan yang signifikan antara flow saliva pada kelompok risiko karies tinggi dan rendah secara statistik.

\section{PEMBAHASAN}

Hasil penelitian menunjukkan 34 subjek yang telah dikategorikan menjadi kelompok risiko karies tinggi 
sebanyak 17 subjek dan kelompok risiko karies rendah sebanyak 17 subjek kemudian dilanjutkan ke pemeriksaan kedua yaitu pengukuran flow saliva tanpa stimulasi yang menunjukkan bahwa terdapat perbedaan flow saliva tanpa stimulasi yang signifikan antara kelompok subjek risiko karies tinggi dan kelompok subjek risiko karies rendah sesuai dengan penelitian Animireddy, et al. ${ }^{13}$ Rerata flow saliva tanpa stimulasi lebih tinggi pada kelompok risiko karies rendah dibandingkan dengan kelompok risiko karies tinggi. Penelitian Moura ${ }^{6}$ menjelaskan bahwa risiko karies dipengaruhi oleh saliva, apabila jumlah saliva yang berbanding lurus dengan flow saliva berkurang dan komponen-komponen kimia saliva berubah maka akan menyebabkan peningkatan risiko karies. Sebaliknya bila saliva cukup, maka saliva dapat melindungi gigi dari pengaruh buruk bakteri dan plak sehingga mengurangi risiko karies gigi.

Variasi flow saliva tanpa stimulasi pada setiap subjek dengan risiko karies tinggi maupun rendah terbagi menjadi 2 kategori yaitu 12 subjek dalam kategori flow saliva yang rendah, 22 subjek dalam kategori flow saliva tinggi, dan tidak terdapat subjek yang mengalami hiposalivasi, sesuai dengan penelitian Torres et al. ${ }^{14}$ menjelaskan bahwa flow saliva pada individu yang sehat dapat bervariasi sesuai dengan faktor-faktor yang berbeda. Dawes ${ }^{15}$ menjelaskan bahwa terdapat tingkatan flow saliva tanpa stimulasi. Nilai normal sebesar 0,3-0,4 ml/ menit, dengan kisaran luas. Tingkat flow saliva $<0,1$ $\mathrm{ml} /$ menit maka disebut hiposalivasi. Hiposalivasi mempengaruhi kesehatan mulut dan mempengaruhi kualitas hidup. Hiposalivasi terjadi karena efek dari penuaan, beberapa penyakit sistemik, dan pengobatan yang mengurangi produksi saliva. Saliva adalah kunci dalam homeostasis rongga mulut, fungsi, dan pemeliharaan kesehatan mulut. ${ }^{16}$

Perbedaan flow saliva pada perempuan dan laki-laki dalam penelitian dikarenakan adanya variasi massa kelenjar pada setiap individu, perbedaan dalam pola hormonal, dan perbedaan BMI (Body Mass Index). ${ }^{17}$ Sampel pada penelitian ini adalah anak usia 11 dan 12 tahun yang dijadikan usia pemantauan global karies dan kurang mengetahui cara memelihara kebersihan dan kesehatan gigi dan mulut. Usia 11 dan 12 tahun masih dalam satu kelompok usia peralihan dari kanak-kanak menjadi remaja dengan karakteristik jasmani, psikis, dan perubahan hormonal yang sama. Flow saliva pada anak-anak memiliki jumlah yang lebih banyak dibandingkan dengan orang dewasa dan usia lanjut. Lopez et al ${ }^{18}$ melaporkan tingkat flow saliva tanpa stimulasi sebesar $0,27 \pm 0,14$ pada kelompok anak usia 5-12 tahun. Flow saliva pada kelompok usia anak dan dewasa memiliki perbedaan dengan kelompok usia lanjut. Flow saliva tidak distimulasi dihasilkan terutama oleh kelenjar submandibula sebanyak 65$70 \%$, sedangkan pada usia lanjut jaringan sekresi dari kelenjar submandibular hilang secara bertahap dan terjadi penggantian dengan jaringan lemak dan jaringan ikat. Usia lanjut memiliki pengaruh negatif terhadap flow saliva. ${ }^{17}$

Penurunan flow saliva dapat mengurangi sistem pertahanan rongga mulut sehingga menyebabkan rentan terjadinya karies. ${ }^{1}$ Hasil pengukuran flow saliva tanpa stimulasi pada penelitian ini dipengaruhi berbagai faktor. Flow saliva yang tinggi dapat dipengaruhi karena tidak mengkonsumsi makanan apapun selama 1 jam sebelum pengumpulan saliva atau sedang dalam keadaan lapar, sehingga sekresi saliva secara impulsif dengan mencium bau makanan, melihat makanan, atau dengan memikirkan dan membayangkan makanan saja.

Flow saliva dapat distimulasi dengan pengunyahan atau adanya makanan. Rasa asam dapat meningkatkan 10 kali lipat flow saliva. ${ }^{19}$ Flow saliva yang rendah pada subjek bisa disebabkan karena stres, sehingga terjadi perubahan psikologi pada seseorang seperti cemas, stres, dan depresi dapat mempengaruhi kerja sistem saraf simpatik yang menyebabkan terjadinya vasokonstriksi kelenjar saliva sehingga flow saliva menurun. Penurunan flow saliva dapat mengurangi kebersihan rongga mulut. Mayoritas masyarakat di pedesaan memiliki keadaan sosial ekonomi yang rendah. Kemampuan ekonomi yang kurang akan kesulitan untuk memenuhi kebutuhan pokoknya, sehingga masalah rongga mulut pun terabaikan. SDN Cikawari merupakan sekolah yang terletak di pedesaan tepatnya di Desa Mekarmanik yang merupakan desa binaan Universitas Padjadjaran dengan kriteria desa tertinggal menurut Bappenas $^{20}$, dengan perekonomian masyarakat tergolong kurang, dimana sebagian besar penduduk bekerja sebagai buruh tani dan fasilitas kesehatan kurang memadai, letak puskesmas yang jauh dan tidak ada tempat praktik khusus dokter gigi di Desa Mekarmanik. 


\section{SIMPULAN}

Berdasarkan hasil analisis data dan pembahasan yang telah dilakukan pada bab sebelumnya, maka simpulannya adalah terdapat perbedaan flow saliva tanpa stimulasi pada anak usia 11-12 tahun dengan risiko karies tinggi dan rendah di SDN Cikawari Kabupaten Bandung.

\section{DAFTAR PUSTAKA}

1. Brosky ME. The role of saliva in oral health. Strategies for prevention and management of xerosmotia. J Support Oncol 2007. h. 215-25.

2. Wong DT. Salivary diagnostic. NIH Public Acess 2008;96(1):37-43.

3. Humairo I, Apriasari ML. Studi deskripsi laju aliran saliva pada pasien diabetes mellitus di RSUD Ulin Banjarmasin J PDGI 2014;63(1):8-13.

4. Fabian TK, Hermann P, Beck A, Fejerdy P, Fabian G. Salivary defense proteions: their network and role in innate and acquired oral immunity. Int J Mol Sci. 2012;13(4):4295-320. DOI: 10.3390/ ijms13044295. Epub 2012 Apr 2.

5. Amerongen A. Ludah dan kelenjar ludah arti bagi kesehatan gigi. Yogyakarta: Gajah Mada University Press, 1991 : 6-7,23-41.

6. Moura, Dias JK, Barros LA. 2008. Quantitative assessment of stimulated saliva flow rate in children and adolescents. Ciencia J Dent Science 2008:23(4):380-3.

7. Kidd, EAM, Safrida F, Narlan S, Bechal SJ. Dasar dasar Karies Penyakit dan Penanggulangannya. Jakarta: EGC, 1991. h. 1-17.

8. Navazesh M, Kumar SKS. Measuring salivary flow: Challenges and opportunities. J Am Dent Assoc (JADA) 2008. May;139 Suppl:35S40S. DOI: https://doi.org/10.14219/jada. archive.2008.0353.

9. Hofman LF. Innovative non-or minimallyinvasive technologies for monitoring health and nutritional status in mothers and young children. ASNS 2001;1623-4.
10. Putz R, Pabst R. Sobotta: Atlas der Anatomie des Menschen. 22 ${ }^{\text {nd }}$ ed. SuyonoJ, Sugiharto L, Novrianti A, Liena, penerjemah. Sobotta:Atlas Anatomi Manusia. Jilid 1. Jakarta: EGC, 2007.

11. Novrianti A, Liena, penerjemah. Sobotta: Atlas Anatomi Manusia. Edisi 22. Jilid 1. Jakarta: EGC, 2007.

12. Hansen Ch. Wala, Gambaran status karies gigi anak usia 11-12 tahun pada keluarga pemegang JAMKESNAS di kelurahan Tumatangtang I kecamatan Tomohon Selatan. Jurnal e-Gigi. 2014.

13. Animireddy D, Reddy Bekkem VT, Vallala P, Kotha SB, Ankireddy S, Mohammad N. Evaluation of $\mathrm{pH}$, buffering capacity, viscosity and flow rate levels of saliva in caries-free, minimal caries and nursing caries children: An in vivo study. Contemp Clin Dent 2014;5(3):324-8.

14. Torres SR, Nucci M, Milanos E, Pereira RP, Massaud A, Munhoz T. Variations of salivary flow rates in brazilian school children. Braz Oral Res 2006;20(1):8-12.

15. Dawes C. Salivary flow patterns and the health of hard and soft oral tissues. J Am Dent Ass 2008; 139:185-245.

16. Gupta A, Joel B. Epstein; Herve Sroussi. Hyposalivation in Elderly Patients. J Can Dent Assoc 2006;72(9):841-6.

17. Sawair, Faleh A, Ryalat S, Mohammad Shayyab, and Takashi Saku. 2009. The Unstimulated Salivary Flow Rate in a Jordanian Healthy Adult Population. J Clin Med Res. 2009;1(4):219-25.

18. López ME, Colloca ME, Páez RG, Schallmach JN, Koss MA, Chervonagura A. Salivary characteristics of diabetic children. Braz Dent J 2003;14:26-31.

19. Walsh LJ. Clinical aspects of salivary biology for the dental clinician. International Dentistry South Africa 2008.

20. Badan Perencanaan pembangunan Nasional (BAPPENAS). Visi dan arah Pembangunan jangka panjang (PJP). Jakarta: Presiden Republik Indonesia. DR. H. Susilo Bambang Yudhoyono. 2005. 